\title{
Exploring Strategic Management and Teachers Workload in School
}

\author{
Mohd Faiz Mohd Yaakob, Mat Rahimi Yusof, Mohd Yusri Ibrahim
}

\begin{abstract}
Strategic management is a key to improve the quality of education. These trusts and tasks are carried out by teachers as the implementer of educational policy. However, behind this agenda and mission, teacher's workload should be noted as an importance factor to implement this. A journey of thousand miles must begin with the first step, so the purpose of this micro study are to explore the implementation of strategic management and teacher's workload in school. Findings showed teachers lack of understanding effectiveness strategic management because of the teacher's workload.
\end{abstract}

Keywords : Strategic Planning in Education, Educational Management, Educational Administration

\section{INTRODUCTION}

This article will develop a critique of one aspect of school administration namely strategic planning. Questions of whether strategic planning has had any impact on education performance are still debated [1];[2];[3];[4]. Teachers are one of the critical contributing factors in improving development quality of education. The process of producing quality teachers can be implemented through the efforts of education leaders and administration that understand and practice the strategic management approach. Accordingly, strategic management is required to ensure the improvement of the quality of education. Strategic management is also called future planning or term planning forecast based planning [5]. As a method for key administration, instruction frameworks ought to be dissected and thoroughly considered as far as pertinence, proficiency, viability, effect, and manageability: for instance, one will ponder whether the contributions to the training framework are pertinent for tending to the requirements, to what degree the procedures are proficiently determined and how well the foreseen yields are adequately delivered. Outcomes should be weighed in terms of their impact and sustainability. Strategic management involves the power of the school's efforts to make organizational planning work and make positive changes to the school. Indeed, management involves four basic stages: analysis, planning, implementation and evaluation [6]. Therefore, the conclusion from this study suggest an effective strategic to reduce teacher's workload.

Revised Manuscript Received on September 22, 2019.

* Correspondence Author

Mohd Faiz Mohd Yaakob*, School of Education and Modern Languages. Email: mohdfaizmohdyaakob@gmail.com

Mat Rahimi Yusof, School of Education and Modern Languages. Email: mrahimiy@uum.edu.my

Mohd Yusri Ibrahim, Universiti Malaysia Terengganu

\section{STRATEGIC MANAGEMENT IN SCHOOL}

The definition of strategic management is diverse. The diversity of the definition is based on the context of the researcher. Strategic management refers to a set of decisions and actions as a result of planned implementation to achieve organizational goals. In addition, the planned implementation involves activities that start from organizational vision formation to assess the success of strategic processes as inputs for future decision making [7]. In a modern world, we can state that key administration is a continuum of progressive stages, basic examination of a framework, arrangement definition, and examination, activity arranging, administration and checking, audit and assessment. Experience and lessons learned from usage, observing and assessment give input to changing the current programmed or for the following cycle of arrangement definition and activity arranging [8].

Meanwhile, strategic management is an orderly effort to produce specific decisions or actions to establish an organization's direction. In order to achieve this goal, strategic management needed extensive data and information, focused planning and taking into account the implications of the future as a result of today's action [9]. However, not all organizations are success with their strategies [10], there are some issues must be solve before implementation strategic management in school.

Thus, to improve teachers' professionalism, strategic management approach is to managing such human resources. His suggestion is the need for school leaders to do some of the following: choosing quality teachers, providing training to improve teacher effectiveness, improve student achievement and reduce the performance gap between effective and less effective pupils [11].

However, the effectiveness of teaching practices does not mean that teachers have effective teaching methods, but their teaching content should meet the curriculum requirements consistent with the changing environment [12]. Furthermore, the effectiveness of teacher teaching practices is achieved through a collaborative culture amongst school girls [13]. There are various assessment mechanisms to evaluate the effectiveness of teacher teaching practices such as benchmarking evaluation of pupils at district and state level, general test for pupils at the end of secondary school level, global teacher quality benchmarking and licensing teaching high-achieving teachers [14].

In short, an education improvement strategy should place effective teaching practices as a key strategy for improvement and strategic management is a risky management [15]. In order 
to create effective teaching practices, the responsibility of formation is not only on the individual shoulder of a teacher or a volunteer business of the school but should be implemented at the school organization and education department involving a group of collaborative individuals [16]

\section{TEACHERS WORKLOAD}

In education, studies on teacher workloads have grown rapidly [17] satisfaction among teachers [18];[19]. Meanwhile, workloads are determined by the relationship between task demands, feedback on the situation of task implementers, actions, skills and knowledge that individuals have in carrying out their duties. This task demands involve physical actions, cognitive tasks and other factors [20]. This means the workload of teachers is also seen as the number of tasks that require more time allocated to complete the assignment given to them [21].In addition, the increased workload has a great impact on the job as a teacher [22]. Assessment of workload is seen through less motivated in the workplace, where they are often absent in school, less active in their work and not productive in contributing to school effectiveness [23].

[24] stated that high teacher workloads would lead to a reduction in satisfaction and thereby increase pressure on them, which will affect the effectiveness of teaching. In addition, some teachers are able to control the workload by reducing their commitment to teaching and learning through reducing input them into teaching tasks [25]. In fact, there are now teachers who had to quit the teaching profession as a stress-bearing effect that they could not handle well [24].[26] find that the workload is an opportunity for teachers to learn and excellent faster. As a result, as workers, they will be exposed to tasks that can give them more experience. In fact, the burden of workload can be a positive influence to increase productivity [27]

Increased workloads do not necessarily have negative effects; on the contrary, it is seen because of the lack of ability to adapt to improvements in work that can impede performance. In this regard, workload among teachers can be reduced by raising the level of resources, increasing the number of teachers and activities that contribute to increased job satisfaction. This relates to studies by [23] that staffs committed to organizations are more likely to do their best and exhibit high involvement in the organization [23]

Therefore, advances and developments, administrative support, and timing are the factors for planning and training are among the potential factors for reducing workload [27]. It is clear that the task of school administration ability to facilitate the awareness of school objectives without increasing the workload to a level that teachers cannot accept [28]. Administrators of school can actually reduce the workload of teachers, just need to be active in order to avoid the use of uncontrolled teachers in achieving organizational goals [29]. Strategic management and strategic planning require special training for teachers [30].

\section{METHODOLOGY}

The philosophies of this study using Pragmatism focus upon the details of situation, a reality behind strategic management with small samples and in depth investigations. The approach is deductive because starting to collect data and then explore them to see which themes or issues to follow up and concentrate on [31]; [32]; [32]. The strategies of this study using case study with qualitative as mono method. The research onion as shown as Figure 1. Cross sectional as time horizons and these studies used micro method of triangulation. Qualitative methods offer an effective way of evidences. We have conducted this study at school to see the workload of teachers in implementing strategic management. Method triangulation involves the use of multiple methods of data collection about the same phenomenon [34].

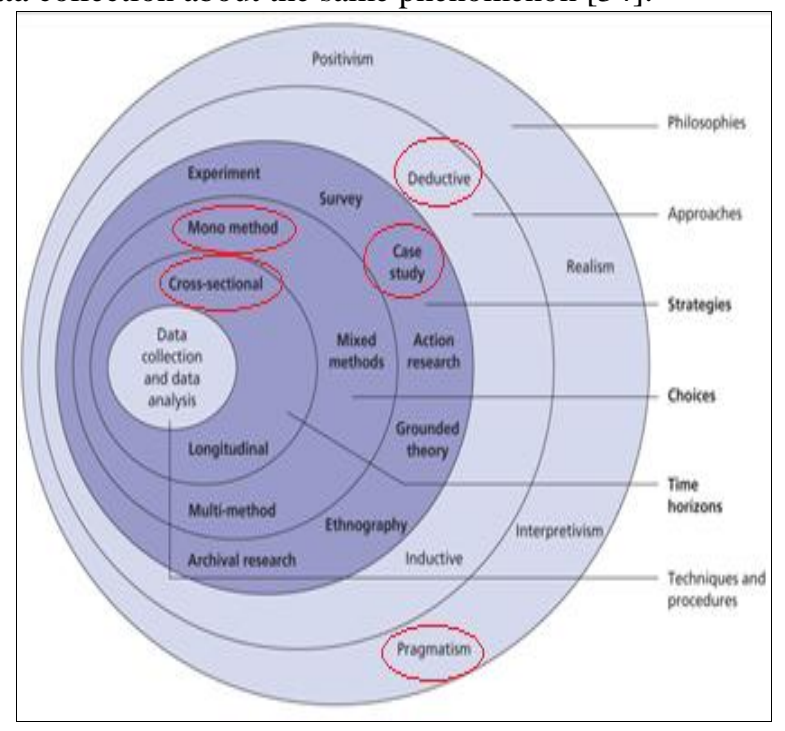

Figure 1. Research Onion (Saunders, 2012)

\section{DATA COLLECTION AND ANALYSIS}

Firstly, we have started with document analysis. Document analysis is a systematic procedure for reviewing or evaluating documents, both printed and electronic material. Like other analytical methods in qualitative research, document analysis requires that data be examined and interpreted in order to elicit meaning, gain understanding, and develop empirical knowledge [33]; [35]. A total of three important documents have been analyzed based on table 1 . This document requires a real understanding from the teachers. Teachers should not be left alone in understanding the aspirations of Ministry of Education (MOE). This document has been well-documented and we find that efforts to have strategic management have been done as the basic education policy needs. However, this requirement comes with pressure on teachers in performing clerical work such as file preparation

Secondly, we have conducted observation. The researcher takes field notes on the behavior and activities of individuals at the school as research site. In these field notes, the researcher records, in semi structured way activities at the school. The form of observation has been used to see the implementation of the strategic management by the school. We used observation because these methods are useful in a

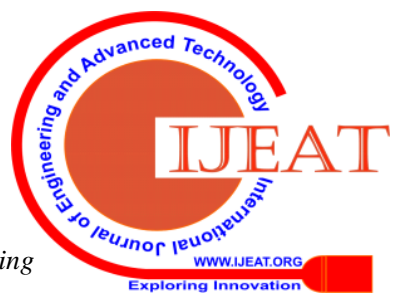


variety of ways and to check for nonverbal expression of feelings, determine who interacts with whom, grasp how participants communicate with each other and check for how much time is spent on various activities.

We found the administration of school emphasized teacher's efforts to ensure transformational in education consistent with Malaysian Education Blueprint 2013-2025 [36]. This causes positive changes to occur, but give effect in the work pressure. We triangulate documents analysis with observation. This type of triangulation can bring both confirmations of findings from different perspectives, adding validity to the phenomenon of interest [37]. Triangulation or multiple methods of data collection and analysis will be used, which strengthens reliability as well as internal validity[38].

Finally, we distributed open ended questionnaire among 23 teachers. First, the coding is performed from the investigator's point of view, and can be performed by a computer program. Secondly, the point of view of the respondent is acknowledged. Here, the computer can be used as a management tool, but the coding must be performed by a human coder. The choice of one of these methods depends on what the investigator is looking for and has consequences for how to proceed. When the representational coding is applied, there are questions of intercoder reliability. The codes to be used should be decided upon before or during the coding process [39].

\section{CONCLUSION}

The present study makes several noteworthy contributions to future teachers training. Continuous professional development (CPD) could prepare workshop for the teachers strategic management as reduce teachers workload toward improve quality of education. This micro research extends our knowledge about strategic management in school. In this exploration, the aim was to assess strategic management and teachers' workload.

Each evidences needs to be stored by the teacher for the Malaysian Quality Education Standard 2 File (SKPMG2). This showed the increasing of teacher workload. This study has successfully explored that one of the factors that caused the workload of teachers is strategic management. Strategic management has led to increased clerical work for teachers. Effective strategic management is needed to make improvements. Costs such as paper use are increasing so as to meet the required pieces of evidence.

Teachers' understanding of the documents is also important. It turns out that teachers only provide strategic management without understanding the effectiveness of the activities to be carried out. The main contribution of this research will serve as a base for future studies about strategic management. For the conclusion, each policy to be implemented by MOE must have good research and well-be planning because it is will effect to the teacher's workload and the job satisfaction. We hoped that this study will realize the authorities to act more effectively in the future. Thus, the strategy and implementation of school achievement plans is constrained by very policy context that shapes planning in schools and assess the success of that planning.

\section{ACKNOWLEDGMENT}

This research was supported by RIMC UUM College Research Grant, Code S.O: 14237

\section{REFERENCES}

1. Les Bell, (2002). Strategic planning and school management: full of sound and fury, signifying nothing?, Journal of Educational Administration, Vol. $40 \quad$ Issue: $4, \quad$ pp.407-424 https://doi.org/10.1108/09578230210440276.

2. Chance, S. (2010). Strategic by design: Iterative approaches to educational planning. Planning for Higher Education, 38(2), 40-54.

3. Mintzberg, H. (1994). The rise and fall of strategic planning: Reconceiving roles of planning, plans and planners. New York, NY: The Free Press.

4. Nauffal, D. I., \& Nasser, R. N. (2012). Strategic planning at two levels: Contrasting strategic planning processes at Qatar University (public) and Lebanese American University (private). Planning for Higher Education, 40(4), 32-39.

5. Istocescu, A. (2015). Strategia şi managementul strategic al organizaţiei: concepte fundamentale. Aplicaţii manageriale A.S.E. Bucureşti.

6. Thompson, J. L. (2013). Strategic management: Awareness and change. London: International Thomson Business Press.

7. Pearce, J. A., \& Robinson, R. B. (2000). Strategic management: Formulation, implementation, and control. New York: McGraw-Hill.

8. UNESCO, National Education Sector Development Plan: A result based planning handbook, Paris: UNESCO, 2006.

9. Bryson, J. M. (1995). Strategic planning for public and nonprofit organizations. San Francisco: Jossey-Bass Publishers.

10. Widodo Unissula, (2018). Grand Theory Model of Strategy Quality: Strategic Asset Approach at Industry, Academy of Strategic Management Journal, 17 (2).

11. Odden, A. R. (2015). Strategic management of human capital in education. New York, NY: Routledge.

12. Goldhaber, Dan, \& Dan Player. (2005). What different benchmarks suggest about how financially attractive it is to teach in public schools. Journal of Education Finance, 30(3), 211-230.

13. Milanowski, Anthony \& Allan Odden. (2008). Do teacher pay levels matter? Madison: the University of Wisconsin, Wisconsin Center for Education Research, Consortium for Policy Research in Education.

14. Levin, J. D., \& M. Quinn. (2013). How we keep high-quality teachers out of urban classrooms. New York: The New Teacher Project

15. Yureva, O.Y, Yureva, O.V, Burganova, L.A, (2016), Strategic Management in Higher Education System: Methodological Approaches, Academy of Strategic Management Journal, 15, (2).

16. Miles, Karen Hawley, Allan Odden, Sarah Archibald \& Mark Fermanich. (2004). Inside the black box of school district spending on professional development: Lessons from five urban districts. Journal of Education Finance, 30(1), 1-26.

17. Peters, J. (2012). Workload, stress, and job-satisfaction among Waldorf teachers: An Explorative study. Research on Steiner Education, 3(2), 111-117.

18. Smith, M. \& Bourke, S. (1992). Teacher stress: Examining a model based on context, workload, and satisfaction. Teaching and Teacher Education, 8(1), 31-46.

19. Timms, C., Graham, D. \& Cottrell, D. (2007). "I just want to teach": Queensland independent school teachers and their workload. Journal of Educational Administration, 45(5), 569-586.

20. DiDomenico, A. \& Nussbaum, M. A. (2008). Interactive effects of physical and mental workload on subjective workload assessment. International Journal of Industrial Ergonomics, 38(11), 977-983.

21. Ekanem, E. E. (2012). Beginning teacher educators development and faculty workload management of Universities in the Cross River State of Nigeria. Review of Higher Education in Africa, 4, 41-61

22. Ballet, K. \& Kelchtermans, G. (2008). Workload and willingness to change: Disentangling the experience of intensification. Journal of Curriculum Studies, 40(1), 47-67. 
23.Reyes, P. \& Imber, M. (1992). Teachers' perceptions of the fairness of their workload and their commitment, job satisfaction, and morale: Implications for teacher evaluation. Journal of Personnel Evaluation in Education, 5(3), 291-302.

24. Smith, M. \& Bourke, S. (1992). Teacher stress: Examining a model based on context, workload, and satisfaction. Teaching and Teacher Education, 8(1), 31-46.

25. Easthope, C. \& Easthope, G. (2000). Intensification, extension, and complexity of teachers' workload. British Journal of Sociology of Education, 21(1), 43-58.

26. Shah, S. S. H., Jaffari, A. R., Aziz, J., Ejaz, W., Ul-Haq, I. \& Raza, S. N. (2011). Workload and performance of employees. Interdisciplinary Journal of Contemporary Research In Business, 3(5), 256-267.

27. Butt, G. \& Lance, A. (2005). Secondary teacher workload and job satisfaction do successful strategies for change exist?. Educational Management Administration \& Leadership, 33(4), 401-422.

28. Timperley, H. \& Robinson, V. (2000). Workload and the professional culture of teachers. Educational Management Administration \& Leadership, 28(1), 47-62.

29. Nkweke, G. \& Dollah, S. (2011). Teaching staff strength (TSS) and workload in public senior secondary schools in Ogba/Egbema/Ndoni local government area of Rivers State, Nigeria. Mediterranean Journal of Social Sciences, 2(7), 25-32.

30. Yaakob, M.F.M., Musa, M.R., Habibi, A., Othman, R.(2019). Strategic management and strategic planning in school: Is it worth for teachers? Academy of Strategic Management Journal.18 (3)

31.Goldhaber, Dan, \& Dan Player. (2005). What different benchmarks suggest about how financially attractive it is to teach in public schools. Journal of Education Finance, 30(3), 211-230.

32. Corbin, J. and Strauss, A. (2008) Basics of Qualitative Research (3rd edn). Thousand Oaks, CA: Sage.

33. Yin, R.K. (2009) Case Study Research: Design and Methods (4th edn). Thousand Oaks, CA: Sage.

34. Polit, D.F., \& Beck, C.T. (2012). Nursing research: Generating and assessing evidence for nursing practice. Philadelphia, PA: Lippincott Williams and Wilkins.

35. Saunders, M., Lewis, P. and Thornhill, A. (2012) Research Methods for Business Students. Pearson Education Ltd., Harlow.

36. Ministry of Education, (2013). Laporan Awal Pelan Pembangunan Pendidikan Malaysia 2013 - 2025. Kementerian Pelajaran Malaysia. Putrajaya.

37. Denzin, N.K. (1978). Sociological methods: A sourcebook. New York, NY: McGraw-Hill.

38. Merriam, S.B. (1988) Case Study Research in Education: A Qualitative Approach. Jossey-Bass, San Francis-co.

39. Popping, R. (2015). Analyzing Open-ended Questions by Means of Text Analysis Procedures. Bulletin of Sociological Methodology/Bulletin de Méthodologie Sociologique, 128(1), 23-39. https://doi.org/10.1177/0759106315597389

\section{AUTHORS PROFILE}

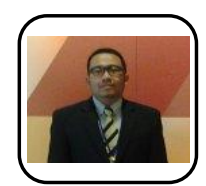

Mohd Faiz Mohd Yaakob is a Senior Lecturer at the School of Education and Modern Languages, College of Arts and Sciences, Universiti Utara Malaysia. He has more than 10 years of teaching experience in school. His research interest area are about Educational Planning \& Policy, Educational Administration and Islamic Studies.

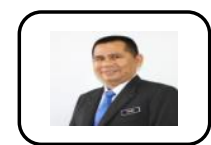

Mat Rahimi Yusof is an educational lecturer from Universiti Utara Malaysia. He has experiences teaching more than 20 years.

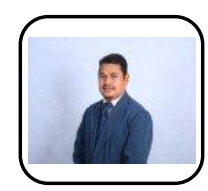

Mohd Yusri Ibrahim is a Senior Lecturer from Universiti Malaysia Terengganu (UMT) He brings to his training sessions and workshops with varied professional experience of more than 10 years 